\title{
Prometheus - an integrated wildfire control system
}

\author{
J. R. S. Nunes, R. V. Soares \& A. C. Batista \\ Forest Sciences Department, Federal University of Paraná, \\ Curitiba, PR, Brazil
}

\begin{abstract}
The main objectives of this paper were to develop a computational system, using the functional modeling that allows to calculate the forest fire danger index through the Monte Alegre Formula (FMA) and the modified Monte Alegre Formula $\left(\mathrm{FMA}^{+}\right)$, and to store information on forest fire occurrence. The system also permits the generation of danger indices and forest fire occurrence statistics from the Context Diagram, the Level 1 and Level 2 Data-Flow Diagrams, and the Entity-Relationship. The Prometheus system was developed using the Borland Delphi 6.0 language with Borland Database Engine - BDE access and Paradox database.
\end{abstract}

Keywords: forest fire, wildfire prevention, wildfire data base, forest protection.

\section{Introduction}

The utilization of a reliable danger index is very important for an efficient fire prevention activities planning and adoption of fast and effective actions on forest fire suppression, in order to reduce the damages and, consequently, the financial losses produced by wildfires.

The danger indices utilize meteorological and climatologic data and the quality of such information is essential to the forest fire prevention and suppression planning (Soares and Batista [13]). Forest fires occurrence and propagation are strongly associated to the weather conditions or climatic aspects. Fire intensity and rate of propagation of wildfires are directly linked to the relative humidity, air temperature, wind speed, and precipitation (Cheney [1]; Schroeder and Buck [8]; Heikkila et al [4]; Soares and Batista [13]).

The Monte Alegre Formula (FMA), developed by Soares [10], is the fire danger index most extensively used in Brazil. It is based on two meteorological 
variables, relative humidity and precipitation, both measured at 1:00PM. The modified Monte Alegre Formula $\left(\mathrm{FMA}^{+}\right)$, developed by Nunes [5], incorporated the wind speed to the original FMA.

In Brazil, the lack of integrated information at national or regional levels and the deficiency of computational tools bring serious problems to the people who work in fire control activities. Some forest companies have difficulties to plan their activities on fire prevention due to the lack of proper tools that would help them to daily calculate the danger indices. The deficiency on monitoring and adoption of adequate fire control policies in certain biomes and conservation units have induced to incalculable damage to the biodiversity of some Brazilian ecosystems.

The objectives of this research were: $i$. to develop a computational system based on the functional modeling (Yourdon [14]; Gane and Sarson [3]; Pompilho [7]) and the data modeling (Silberschatz et al [9]; Date [2]) to calculate an store the Monte Alegre Formula - FMA (Soares [10, 11]) and the modified Monte Alegre Formula - $\mathrm{FMA}^{+}$(Nunes [5]), the Brazilian forest fire danger indices; $i$. to store fire occurrence data in order to generate updated statistics on forest fire occurrence. Other functionalities were incorporated to the system, like the relative humidity estimation at 1:00 PM base on the 9:00AM and 3:00PM data, and the relative humidity calculation based on the psychrometer temperatures.

\section{Methods}

\subsection{Functional modeling}

The forest fire integrated system (Prometheus) was based on the functional modeling (Yourdon [14]); Gane and Sarson [3]; Pompilho [7]) and the data modeling (Silberschartz et al [9]; Date [2]), such as presented as follows. The context and data flow diagrams define the main process that compound the system.

\subsection{Context diagram}

The system takes, as inputs, meteorological and fire occurrence data, and provides information on fire danger and fire occurrence statistics, helping the technicians to make decisions on forest fire control activities (Figure 1).

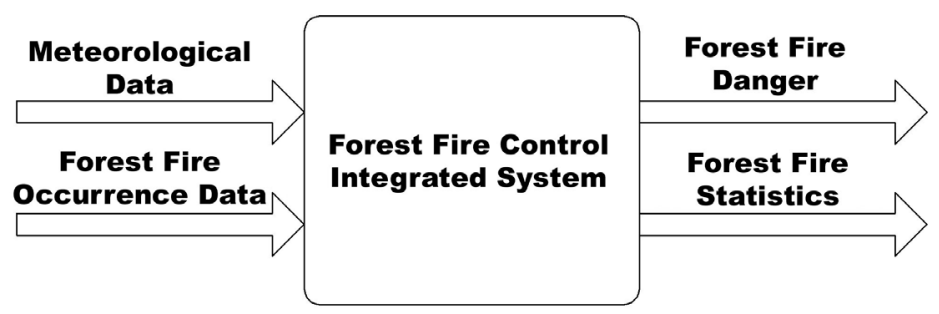

Figure 1: $\quad$ Context diagram. 


\subsection{Data flow diagrams}

The main processes that will take part in the system were defined and divided in two groups: Forest fire danger indices determination and Forest fire statistics database updating (Figures 2 and 3).

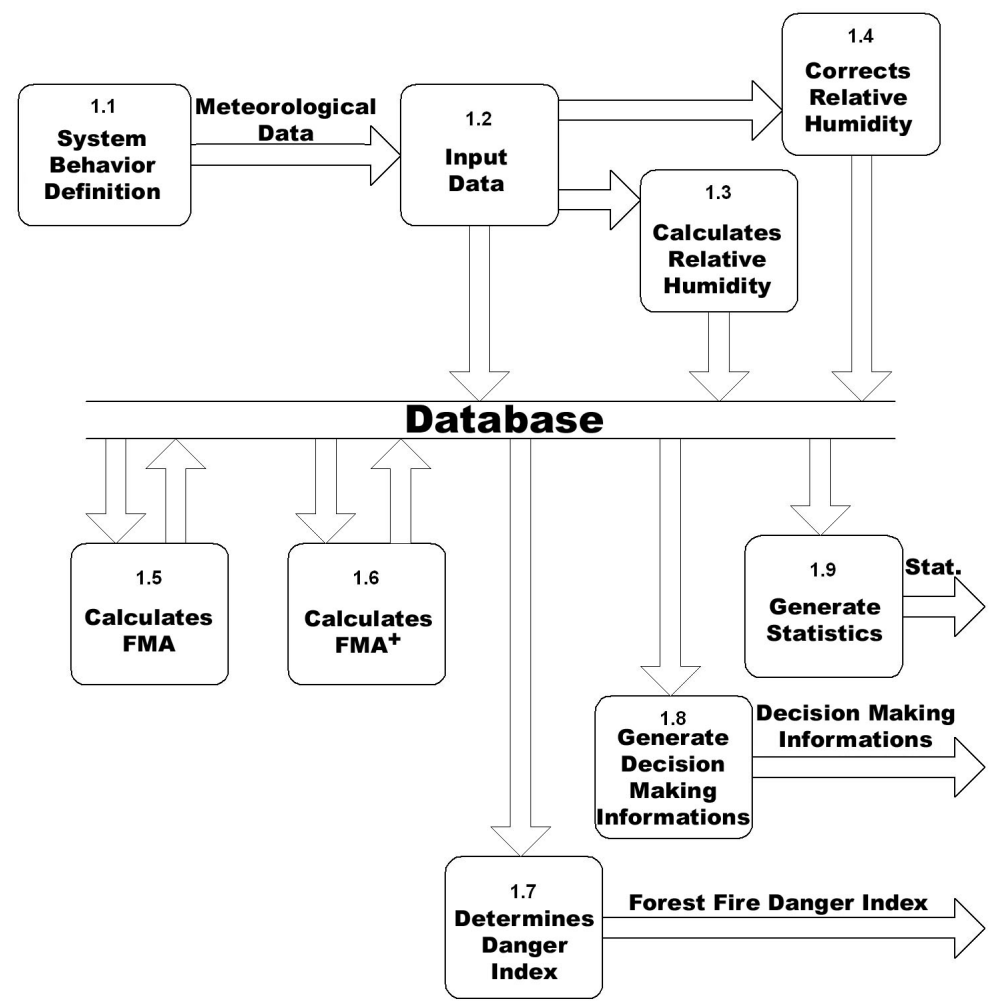

Figure 2: Data flow diagram for fire danger index determination.

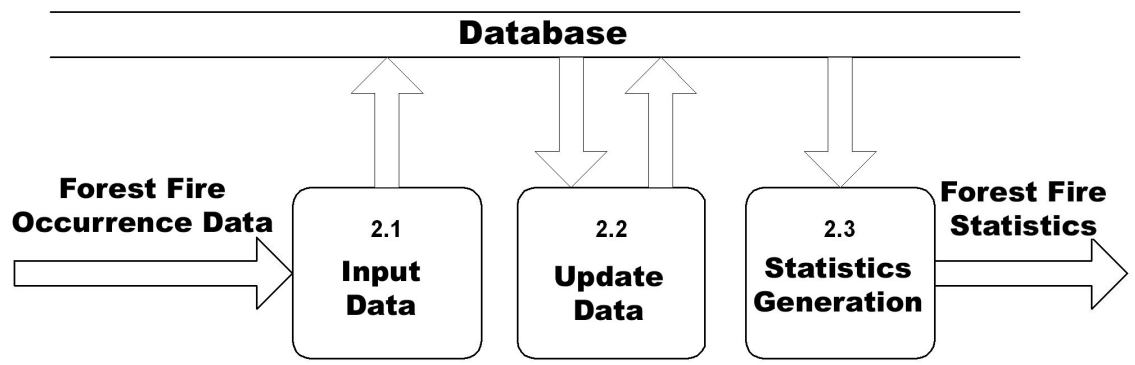

Figure 3: Data flow diagram for fire statistics database update. 


\subsection{Data modeling}

The majority of the database follows a relational model, characterized by a collection of tables, each one designed by a proper name. Each database must present a project that takes in account the information organization and the utilization of techniques that leads to a good performance and makes easy the necessary maintenances. The database project considers two phases: the conceptual and the logical models.

\subsection{The conceptual model}

The conceptual model defines the data structure that takes part in the system. The model presents the capacity of meteorological data storage through the Data_Climate entity; forest fire danger index through the Danger_Index entity; and data on fire occurrence through the Occurrence entity.

\subsection{The logical model}

In the logical model specification a description of all the tables concerning to the meteorological data, the fire anger indices, and the forest fire occurrences was done. For some supplementary tables the options to fill up the fields were defined to standardize the information.

\subsubsection{Description of the meteorological data and fire danger indices tables}

Data_climate (date, local, altitude, relative_humidity_13, daily_precipitation, wind_speed_13)

Operations: inclusion, alteration, exclusion.

Danger_index (date, local, summation, Danger FMA, danger degree, value, $\mathrm{FMA}^{+}$, DangerFMA ${ }^{+}$)

Operations: calculated values through the climate table, data exportation.

Restriction (lim inferior, lim superior, deduction).

DangerFMA (code, val_inferior, val_superior, danger_degree)

DangerFMA ${ }^{+}$(code, val_inferior, val__superior, danger_degree)

\subsubsection{Description of the forest fire occurrence tables}

Occurrence (date, local, week day, latitude, longitude, detection_time, controlled_fire_time, suppressed_fire_time, informer, burned_area, detection, cause, fire_type, vegetation, fuel, topography, suppression_technique.

Operations: inclusion, alteration, exclusion.

Week_day (code, day)

Week_day options: Sunday, Monday, Tuesday, Wednesday, Thursday, Friday, Saturday.

Detection (code, means of detection)

Detection options: mobile vigilance, lookout tower, neighbor, aircraft, satellite, other.

Cause (code, cause)

Probable cause options: lightning, incendiary, debris burning, smoking, recreation, railroad, forest operations, miscellaneous. 
Fire_type (code, fire_type)

Fire-type options: soil, surface, crown.

Vegetation (code, vegetation_type)

Vegetation options: native, exotic.

Fuel (code, fuel_type)

Fuel options: grassland, savanna, agriculture, second grow, prairie, native forest, pine, eucalyptus, Brazilian pine, other planted forests.

Topography (code, type_landscape)

Topography options: flat, moderate slope, medium slope, steep.

Suppression technique (code, suppression technique)

Suppression technique options: direct, flank, parallel, backfire, aircraft.

\subsection{Theoretical fundaments for the main algorithms}

\subsubsection{Relative humidity calculation}

The following equations were used to calculate the relative humidity based on the psychrometer dry and wet temperatures (Soares and Batista [12]):

Atmospheric pressure calculation:

$$
\mathrm{P}_{\mathrm{z}}=760(1-0,0065 \mathrm{z} / 288)^{5,2568}
$$

where: $\mathrm{P}_{\mathrm{z}}=$ atmospheric pressure at a certain altitude $(\mathrm{mmHg})$

$\mathrm{z}=$ altitude $(\mathrm{m})$

Maximum water vapor determination:

$$
\mathrm{E}_{\mathrm{T}}=4,58 \times 10^{(7,5 \mathrm{~T} / 237,3+\mathrm{T})}
$$

where: $\mathrm{E}_{\mathrm{T}}=$ maximum water vapor pressure at a temperature $\mathrm{T}(\mathrm{mmHg})$

$\mathrm{T}=$ air temperature $\left({ }^{\circ} \mathrm{C}\right)$

Maximum water vapor pressure for the wet bulb temperature determination:

$$
\mathrm{E}^{\prime}=4,58 \times 10^{\left(7,5 \mathrm{~T}^{\prime} / 237,3+\mathrm{T}^{\prime}\right)}
$$

where: $E^{\prime}=$ maximum water vapor pressure for the temperature $\mathrm{T}^{\prime}(\mathrm{mmHg})$

$\mathrm{T}^{\prime}=$ wet bulb temperature $\left({ }^{\circ} \mathrm{C}\right)$

Actual water vapor pressure determination:

$$
\mathrm{e}=\mathrm{E}^{\prime}-\mathrm{C} \mathrm{P}_{\mathrm{z}}\left(\mathrm{T}-\mathrm{T}^{\prime}\right)
$$

where: $\mathrm{e}=$ actual water vapor pressure $(\mathrm{mmHg})$

$\mathrm{E}^{\prime}=$ maximum water vapor pressure for the temperature $\mathrm{T}^{\prime}(\mathrm{mmHg})$

$\mathrm{C}=$ psychrometer constant

$\mathrm{P}_{\mathrm{z}}=$ atmospheric pressure $(\mathrm{mmHg})$

$\mathrm{T}=$ dry bulb temperature $\left({ }^{\circ} \mathrm{C}\right)$

$\mathrm{T}^{\prime}=$ wet bulb temperature $\left({ }^{\circ} \mathrm{C}\right)$

Relative humidity calculation:

$$
\mathrm{UR}=\left(\mathrm{e} / \mathrm{E}_{\mathrm{T}}\right) 100
$$

\subsubsection{Relative humidity estimation}

The relative humidity at 1:00PM can also be estimated through the relative humidity measured at 9:00AM or 3:00PM, using the following equations (Nunes [6]):

$$
\begin{gathered}
\mathrm{UR}_{13}=e^{\left(2.72976+0.0162192 \mathrm{UR}_{09}\right)} \\
\mathrm{UR}_{13}=2.451510 \mathrm{UR}_{15}^{0.796072}
\end{gathered}
$$




\subsubsection{FMA calculation}

The basic equation to calculate the Monte Alegre Formula is as follows (Soares [11]):

$$
\mathrm{FMA}=\sum_{\mathrm{i}=1}^{\mathrm{n}}\left(100 / \mathrm{H}_{\mathrm{i}}\right)
$$

where: $\mathrm{FMA}=$ Monte Alegre formula

$\mathrm{H}=$ relative humidity $(\%)$, at 1:00PM

$\mathrm{n}=$ number of days without rain $\geq 13,0 \mathrm{~mm}$

Being accumulative, the index has some precipitation restrictions (Table 1).

Table 1: $\quad$ Restrictions to the FMA according to the daily precipitation.

\begin{tabular}{|c|l|}
\hline Precipitation $(\mathrm{mm})$ & \multicolumn{1}{c|}{ Summation restrictions } \\
\hline$\leq 2.4$ & None \\
\hline 2.5 to 4.9 & $\begin{array}{l}\text { Subtract } 30 \% \text { from the FMA calculated in the previous } \\
\text { day and add the }(100 / \mathrm{H}) \text { of the day. }\end{array}$ \\
\hline 5.0 to 9.9 & $\begin{array}{l}\text { Subtract } 60 \% \text { from the FMA calculated in the previous } \\
\text { day and add the }(100 / \mathrm{H}) \text { of the day. }\end{array}$ \\
\hline 10.0 to 12.9 & $\begin{array}{l}\text { Subtract } 80 \% \text { from the FMA calculated in the previous } \\
\text { day and add the }(100 / \mathrm{H}) \text { of the day }\end{array}$ \\
\hline$>12.9$ & $\begin{array}{l}\text { Stop calculation }(\mathrm{FMA}=0) \text { and restart the summation } \\
\text { in the following day or when the rain is } \leq 2.4 \mathrm{~mm} .\end{array}$ \\
\hline
\end{tabular}

The danger degree interpretation follows the scale presented in Table 2.

Table 2: $\quad$ Forest fire danger scale for the FMA.

\begin{tabular}{|c|c|}
\hline MA value & Danger degree \\
\hline$\leq 1.0$ & None \\
\hline 1.1 to 3.0 & Low \\
\hline 3.1 to 8.0 & Medium \\
\hline 8.1 to 20.0 & High \\
\hline$>20.0$ & Very high \\
\hline
\end{tabular}

\subsection{4 $\mathrm{FMA}^{+}$calculation}

The modified Monte Alegre Formula (Nunes [5]), that includes the wind speed, is calculated through the following equation:

$$
\mathrm{FMA}^{+}=\sum_{\mathrm{i}=1}^{\mathrm{n}}\left(100 / \mathrm{H}_{\mathrm{i}}\right) \mathrm{e}^{0,04 \mathrm{v}}
$$

where: $\mathrm{FMA}^{+}=$modified Monte Alegre Formula

$\mathrm{H}=$ relative humidity $(\%)$, at 1:00PM

$\mathrm{n}=$ number of days without rain $\geq 13,0 \mathrm{~mm}$

$\mathrm{v}=$ wind speed at 1:00PM $\left(\mathrm{m} \cdot \mathrm{s}^{-1}\right)$

$\mathrm{e}=$ natural logarithm basis $(2,718282)$ 
The accumulative index is subject to the same precipitation restrictions showed in Table 1. The danger degree interpretation is presented in Table 3.

Table 3: $\quad$ Forest fire danger scale for the $\mathrm{FMA}^{+}$.

\begin{tabular}{|c|c|}
\hline FMA $^{+}$Value & Danger degree \\
\hline$\leq 3.0$ & None \\
\hline 3.1 to 8.0 & Low \\
\hline 8.1 to 14.0 & Medium \\
\hline 14.1 to 24.0 & High \\
\hline$>24.0$ & Very high \\
\hline
\end{tabular}

\section{Results and discussion}

Prometheus is a computational system designed to calculate and store fire danger values using the FMA and $\mathrm{FMA}^{+}$methodologies, as well as to issue reports and graphs related to those indices. It also stores, searches, and emits reports on forest fire occurrences. Other functionalities were also incorporated to the system, like the 1:00PM relative humidity estimation based on the 9:00AM and 3:00PM measurements, and the $\mathrm{RH}$ calculation through the psychrometer temperatures and local altitude.

Consultations, data base exportation to $. d o c, . x l s$, and.$r t f$, reports, graphs and a decision-making module will provide an important support to the fire management technician from a forest company or a conservation unit. Generation and restoration of safety copies preserves the user's information and ensure the system integrity.

\subsection{Main functions}

The main functions of the system are: system configuration, safety copy generation, safety copy restoration, user registration, recording and consultation to fire danger indices, recording and consultation to fire occurrences, reports issuing, graphs visualization, and decision-making suggestions. Figure 4 shows the initial system window.

Only registered users can utilize the system. However, users and passwords can be altered, included and excluded. The only user that cannot be excluded or have the password modified is the one registered as admin, who is authorized to admit new users and change names and passwords.

Figures 5 to 8 show some examples of windows that appear when running the system, like the FMA calculation and recording, stored FMA data retrieving, forest fire occurrences recording, and the $\mathrm{FMA}^{+}$monthly values graph review.

\section{Conclusions}

The Prometheus system was developed in the Windows XP platform, with the objective of offering to the users a simple and easy interface. 
260 Modelling, Monitoring and Management of Forest Fires I

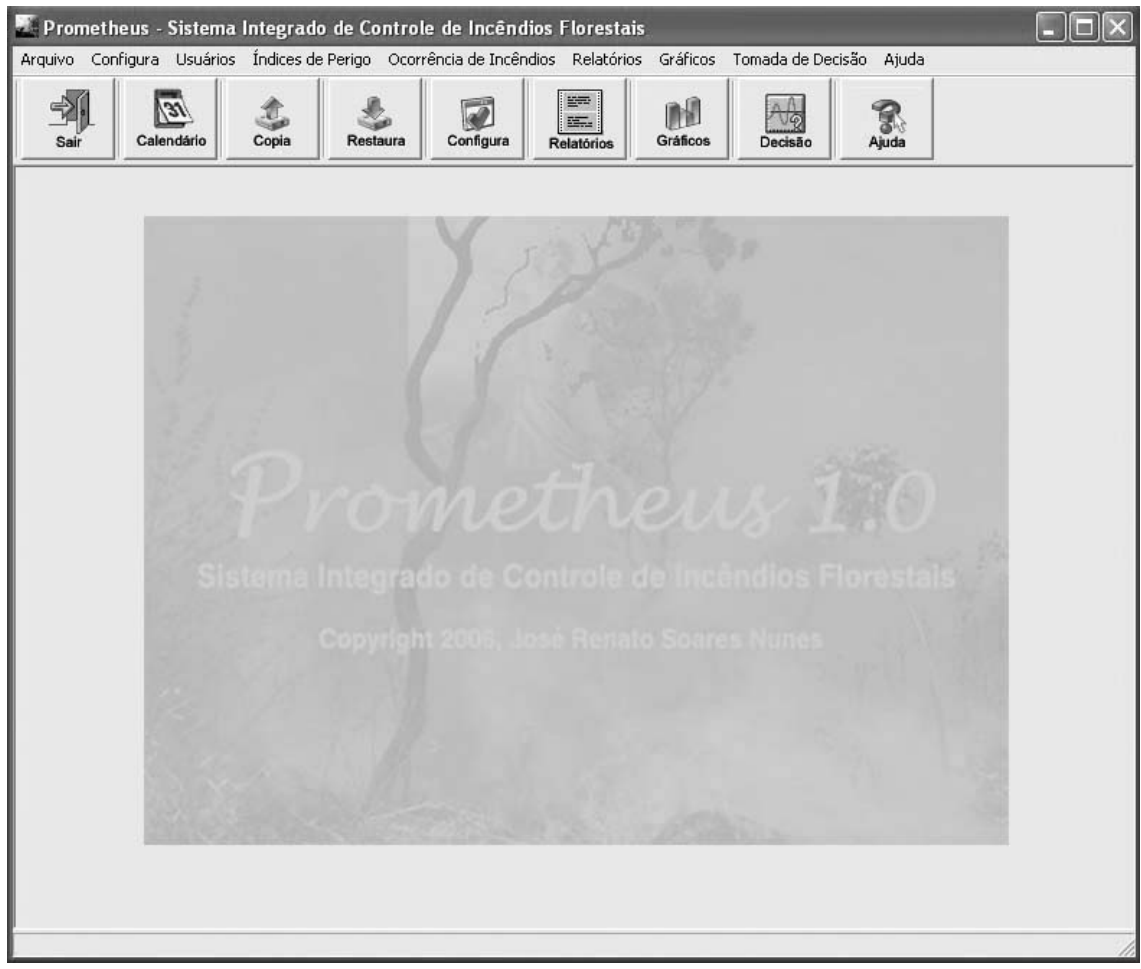

Figure 4: $\quad$ Prometheus system initial window.

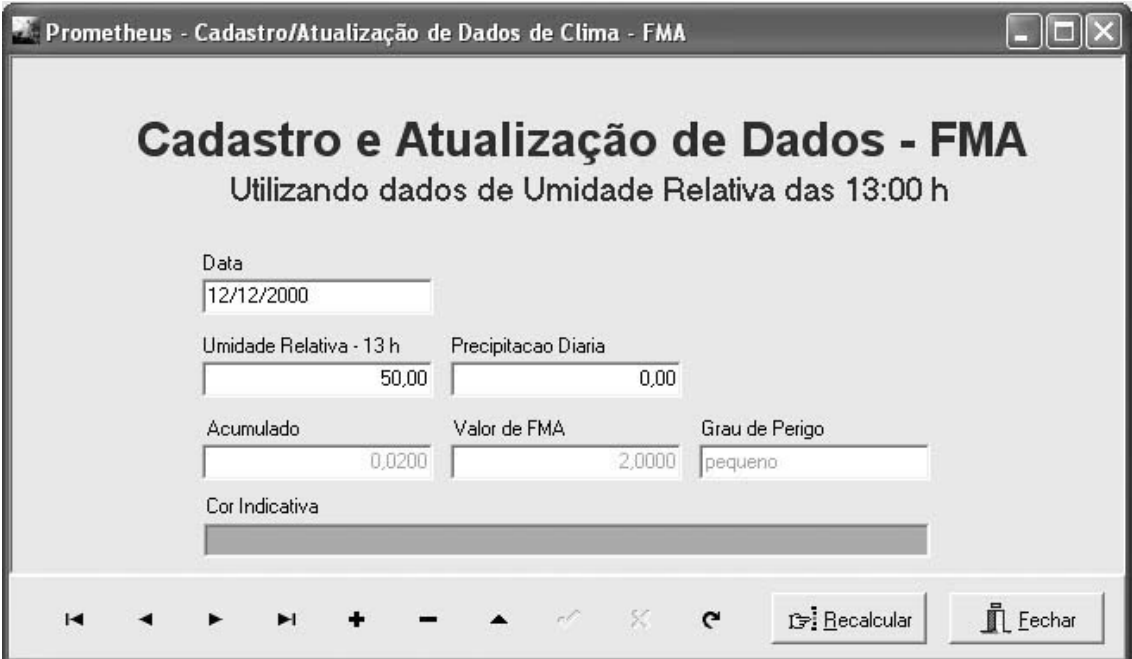

Figure 5: $\quad$ FMA calculation and recording. 


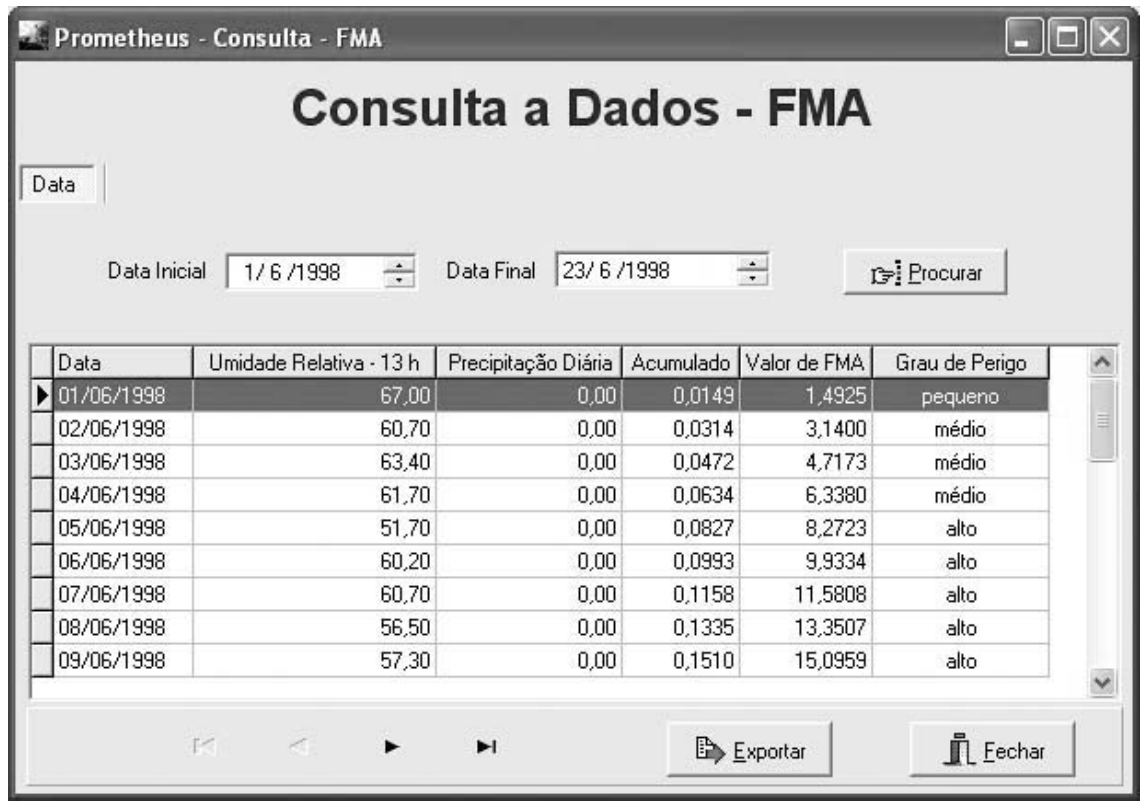

Figure 6: FMA values recorded consulting.

\section{Cadastro de Ocorrência de Incêndios Florestais}

Informações Gerais

\begin{tabular}{|lll} 
Código Gerado Automaticamente & Data & Responsável pelas Informações \\
\hline $12 / 10 / 2000$ & João Gomes dos Santos
\end{tabular}

Caracterização da Área

\begin{tabular}{|c|c|c|c|c|}
\hline Estado & & Município & & \\
\hline Paraná-PR & - & Mandirituba & & \\
\hline Localidade & & Latitude & Longitude & Altitude (m) \\
\hline Espigão & & $22^{\circ} 22^{\prime} 22^{\prime \prime S}$ & $22^{\circ} 22^{\prime} 22^{\prime \prime} \mathrm{O}$ & 940 \\
\hline
\end{tabular}

Caracterização do Incêndio

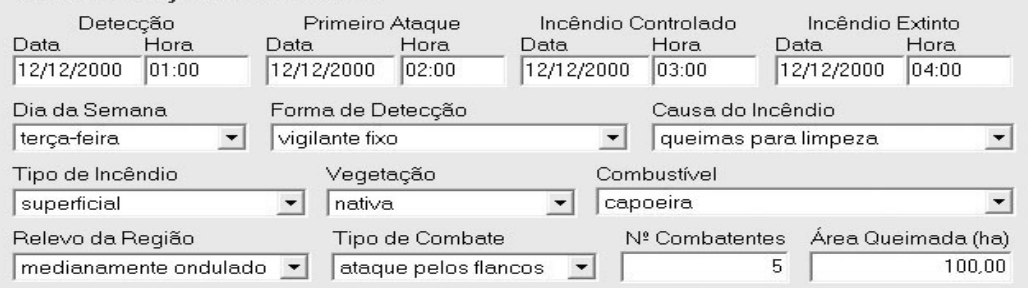

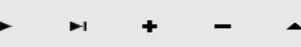

Figure 7: $\quad$ Forest fire occurrence recording. 


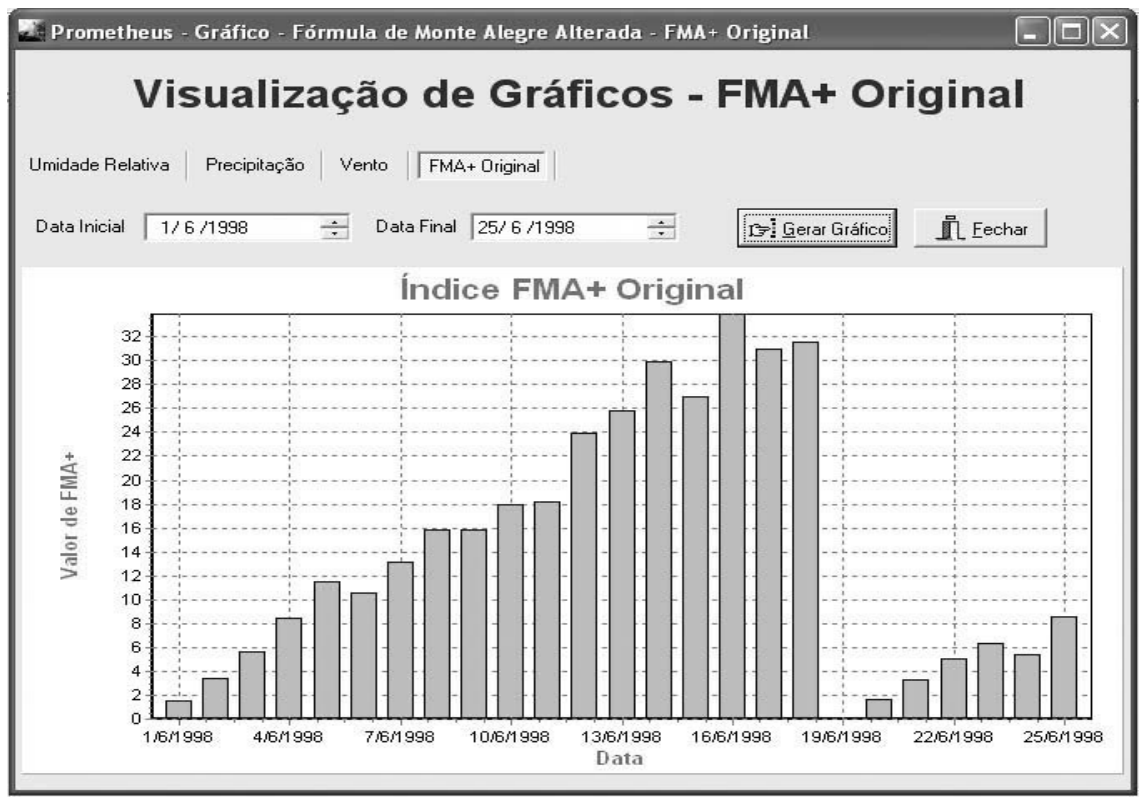

Figure 8: $\quad \mathrm{FMA}^{+}$monthly values graphic visualization.

The system was tested and run perfectly in the Windows 98, what makes possible its installation in that environment.

The concern with the system safety and integrity allows the user the information protection and data recovering in case of misuse, since security copies are made.

\section{References}

[1] Cheney, N. P. Predicting fire behavior with fire danger tables. Australian Forestry, v. 32, n. 2, p. 71-79. 1968.

[2] Date, C.J. Introdução a Sistemas de Bancos de Dados. Rio de Janeiro, Editora Campus, $7^{\mathrm{a}}$ ed., 2000.

[3] Gane, C. and Sarson, T. Análise Estruturada de Sistemas. Livros Técnicos e Científicos, Rio de Janeiro, $18^{\mathrm{a}}$ ed, 257 p. 1995.

[4] Heikkilä, T. V.; Gronovist, R.; Jurvélius, M. Handbook on Forest Fire Control. Helsinki, Forestry Training Programme Publication 21. 239 p. 1993.

[5] Nunes, J. R. S. FMA ${ }^{+}$- Um novo índice de perigo de incêndios Florestais para o estado do Paraná - Brasil. Curitiba, 2005, 150p. (Doutorado em Engenharia Florestal) - Setor de Ciências Agrárias, Universidade Federal do Paraná. 
[6] Nunes, J. R. S., Soares, R. V., Batista, A. C. Ajuste da fórmula de Monte Alegre alterada - $\mathrm{FMA}^{+}$para o estado do Paraná. Revista Floresta, Curitiba, v.37, n. 1, p. 1-14, 2007.

[7] Pompilho, S. Análise Essencial. Guia Prático de Análise de Sistemas. IBPI Press, 1995.

[8] Schroeder, M. J.; Buck, C. C. Fire weather. USDA Forest Service, Agriculture Handbook 360. 229 p. 1970.

[9] Silberschatz, A., Korth, H., Sudarshan, S. Sistema de Bancos de Dados. Makron Books, $3^{\text {a }}$ ed., 1999.

[10] Soares, R. V. Determinação de um índice de perigo de incêndio para a região centro paranaense, Brasil. Turrialba, Costa Rica, CATIE/IICA. 72 p. (Tese de Mestrado). 1972.

[11] Soares, R. V. Índices de perigo de incêndio. Revista Floresta, Curitiba, v. 3, n. 3, p.19-40, 1972.

[12] Soares, R. V.; Batista, A. C. Meteorologia e climatologia florestal. Curitiba, 195 p. 2004.

[13] Soares, R. V.; Batista, A. C. Incêndios florestais: controle, efeitos e uso do fogo. Curitiba, 250p. 2007.

[14] Yourdon, E. Análise estruturada moderna. Rio de Janeiro, Editora Campus, 1992. 